\title{
Replicating of Domestic Security Policy in Malaysian Foreign Policy
}

\author{
Mohammad Agus Yusoff ${ }^{1} \&$ Fakhreddin Soltani ${ }^{1}$ \\ ${ }^{1}$ School of History, Politics, and Strategic Studies (SOHPASS), Faculty of Social Sciences and Humanities, \\ Universiti Kebangsaan Malaysia, Bangi, Malaysia \\ Correspondence: Fakhreddin Soltani, School of History, Politics, and Strategic Studies (SOHPASS), Faculty of \\ Social Sciences and Humanities, Universiti Kebangsaan Malaysia, 43600 UKM, Bangi, Selangor, Malaysia. \\ E-mail: fakhreddinsoltany@gmail.com
}

\author{
Received: December 7, 2012 Accepted: December 17, 2012 Online Published: January 28, 2013 \\ doi:10.5539/ass.v9n2p115 \\ URL: http://dx.doi.org/10.5539/ass.v9n2p115
}

\begin{abstract}
Ethnic and religious conflicts have been one of the critical challenges in multi-ethnic and multi-religious countries. Since 1969, Malaysia, which contains a variety of ethnic and religious groups, has unequivocally been successful in terms of managing ethnic and religious differences in the country. The fundamental basis of Malaysia's ethnic and religious policy has been tolerance, a trait which has no doubt been helpful in dealing with ethnic and religious differences and providing domestic security. According to some scholars, states' domestic and foreign policies follow the same patterns of behaviour, which essentially means that states replicate their domestic policies in foreign policies; this article is to explain whether Malaysian foreign policy is shaped on the basis of internal tolerance and is in turn cooperative towards other countries. In regard to this aim, the article starts out by explaining the Malaysian government's domestic policies towards ethnic and religious groups and subsequently explains the government's foreign policy towards other countries in order to understand if there is replication in the domestic and foreign policy of Malaysia.
\end{abstract}

Keywords: Malaysia, replicate, security, toleration, domestic policy, and foreign policy

\section{Introduction}

One of the critical problems of multi-ethnic countries is the question of how to deal with different ethnic groups and minorities and how this behavior affects their security in the international sphere. Indigenous ethnic groups are most concerned with their autonomy and distinguishing characteristics that set them apart from other groups in the country. This being said, however, ethnic groups' political actions have been mainly reactive rather than proactive towards the aimed actions of the government (Gurr, 1993). In other words, the actions of the government lead ethnic groups to react accordingly. The behavior of the government can be traced in the international sphere. Essentially, states replicate their domestic behavior in the international arena, where they face the reactions of other countries. Thus, it can be said that "conflict breeds conflict" (Lichbach \& Gurr, 2010). This assumption means that societies and social groups have their own complex behavioral patterns of conflict which are endemic and self-generative (Lichbach \& Gurr, 2010).

Therefore, Regime type with its endemic characteristics has a direct impact on the behaviour of the government in domestic and external behaviour. There exists a plethora of literature that emphasizes the impact of regime type on the behaviour of the government. For example, Fox and Sandler (2003) identify a relationship between democracy and tolerance, and by placing democracy and autocracy at two ends of a continuum, argue that "as a state moves closer to the democratic end of the continuum, it becomes more tolerant and discriminates less against minorities, including ethnic and religious minorities". One of the most influential works on this matter is an article by Doyle (1986) that argues that the governments that respect the liberty of their citizens and individuals within their territory, follow peaceful intentions in their foreign policy as well. He concludes that democracies are not inclined to wage war against other democracies.

Other scholars, such as Regan and Paskeviciute (2003), have made connections between other factors. They pinpoint the relationship between women in society and the use of force by the state in the international arena. Their argument is built on the conception of power relationships found in gender studies and feminist theories, and explains how the internal distribution of political power at a societal level will influence the willingness of the ruling elite to engage in militarized interstate disputes and war. In other way, Caprioli and Boyer (2001) 
argue that "states that are characterized by higher levels of gender equality use lower levels of violence during crises than those with lower levels of gender equality". By referring to historical evidence, they argue that levels of gender equality in the domestic sphere are directly related to levels of violence in the international behaviour of the countries.

Some scholars argue that there are relations between level of domestic discrimination and level of violence in countries' foreign policy. For example, Caprioli and Trumbore (2003) argue that domestic norms of discrimination, violence and inequality in domestic spheres of countries lead to a state's increased proneness to use force first when involved in an interstate dispute. By referring to statistical evidence, they explain that there are significant connections between domestic patterns of behaviour and state behaviour at the international level. On this basis, Ekhtiari et al (2011), by studying ethnic conflicts and their effects on international behaviour of countries in the case of Iran over the period of 1997 to 2005, argue that as the level of inequalities among ethnic groups decreased, the level of violent behaviour in foreign policy also decreased accordingly towards Persian Gulf states, the European Union and the United States. Therefore, concerning multi-cultural and multi-ethnic characteristics, this paper is to study Malaysia according to the mentioned idea and explain whether there is a connection between Malaysia's domestic security policy and its external behaviour.

\section{Domestic Diversity and Policies}

Despite the ethnic and religious differences among the population, Malaysia has exhibited three main characteristics in terms of its exports; stability; and investment through people, which seem to be essential for growth. Politics in Malaysia is dominated by ethnic considerations, which are ruled by a federal system of government (Milne \& Mauzy, 1999). Malaysia is a multicultural country in which different ethnicities and religious groups peacefully coexist alongside each other. The domestic security of Malaysia is based on accepting rather than conflicting ethnic differences. In other words, Politics in Malaysia takes consociational form, through which the main ethnic groups share power in the country (Kuok, 2008). The "grand coalition" is the most important characteristic of consociational democracy, by which the government or executive branch includes extra parties so that it can represent the views of a broader chunk of the public (Lijphart, 1977).

Three major ethnic groups, namely Malay, Chinese, and Indian, along with various other minority groups, live in Malaysia. The biggest ethnic group is Malay, which includes more than $50 \%$ of the population, followed by Chinese (23.7\%), Indian (7.1\%), indigenous (11\%), and others (7.8\%) ("Malaysia Demographics Profile 2012"). Islam is the official religion, with most of its followers being of the Malay race. In other words, the three concepts of Malay, Bumiputera (sons of the soil) and Muslim can be considered overlapping concepts that carry the same meaning (Means, 1991). Religions including Buddhist, Christian, Hindu, Confucianism, Taoism, and others have their own followers and traditional ceremonies in the country ("Malaysia Demographics Profile 2012"). This ethnic and religious diversity requires a smart plan to prevent domestic conflicts. Two main solutions can be applied for dealing with minorities: oppressing minorities and toleration. Since its independence in 1957, Malaysia has applied mostly the second approach.

The First Prime Minister, Tunku Abdul Rahman Putra Alhaj called Malaysia a secular state, although during Mahathir's period the policy was changed and Malaysia was declared an Islamic state. This policy led to controversy within the non-Malay community. After that, Prime Minister Abdullah_bin Haji Ahmad Badawi declared Malaysia an Islamic state that was to be ruled by Islamic principles and the Parliamentary democratic principles as stated in the Federal Constitution. It is important to mention that this statement is based on Article 3(1) of the Constitution of Malaysia, which states that Islam is the dominant religion, although other religions are allowed to be practiced in peace and harmony in the Federation (Milne \& Mauzy, 1999). Therefore, although the government has ensured the dominance of Malay-Sunni Islam, other religious and ethnic groups are allowed to have their own traditional ceremonies and public holidays, such as Christmas, Chinese New Year, and Deepavali for Indians.

This article of the Constitution has been an attempt on the part of the Malaysian Government to impel all ethnic and religious groups to live alongside each other peacefully. The latest attempt was the idea of Islam Hadhari Civilizational Islam - which is the basis of moderate Islam that was to strengthen toleration among different religions. The concept of Islam Hadhari was first mentioned in March 2004 during the $11^{\text {th }}$ general election campaign by Abdullah_bin Haji Ahmad Badawi. Islam Hadhari has 10 main principles, which are as follows: “1) faith and piety in Allah (God); 2) a just and trustworthy government; 3) a free and independent people; 4) a vigorous pursuit and mastery of knowledge; 5) a balanced and comprehensive economic development; 6) a good quality of life for people; 7) protection of rights of minority groups and women; 8) cultural and moral integrity; 9) safeguarding the natural resources and environment; and 10) strong defense capabilities" (Ahmad \& Rahman, 
2001).

There have been a number of development policies launched, but the preponderance of Malaysia's significant programmes came after 1971. 1971 was the introduction of the New Economic Policy (NEP), which was launched together with the Second Malaysian Plan, 1971-1975. NEP was designed for the period of 1971-1990. Since then there have been three other master plans: the National Development Policy (NDP) from 1990 to 2000, National Vision Policy (NVP) for the years between 2001 and 2010 (Jawan, 2003), and Vision 2020. The main purpose of the Plans was to alleviate poverty irrespective of ethnicity or religious considerations. Accordingly, the government attempted to provide opportunities in terms of education, jobs and higher incomes for all Malaysians as rapidly as possible (Aun, 2004).

Therefore, the government's main purpose was to make sure that developmental benefits would be distributed among the various ethnic communities in the country (Jawan, 2003). In other words, equity and balance among the ethnic and religious groups has been considered essential to achieving national unity ("U. N. D. P, 2004"). Since independence in 1957, the most challenging ethnic crisis happened on May Thirteenth, 1969, which resulted in the government declaring a state of national emergency (Kessler, 2012). Since then Malaysia has not faced any serious ethnic conflicts. This event made the Malaysian government contemplate ways to prevent similar future upheavals. Development plans were designed in order to serve this goal. Though many non-Malays were sceptical towards the goals of the development plans and considered them beneficial to Malays over non-Malays (Milne \& Mauzy, 1999), the events since then shows that the plans have been successful.

\section{Foreign Policy}

Since its independence in 1957, Malaysia has had six prime ministers: Tunku Abdul Rahman Putra Al Haj (1957-1970), Tun Abdul Razak Hussein (1970-1976), Tun Hussein Onn (1976-1981), Tun Dr Mahathir Mohamad (1981-2003), Tun Abdullah Ahmad Badawi (2003-2009), and Datuk Seri Najib Razak (2009-). The First Prime Minister of Malaysia, Tunku Abdul Rahman, was willing to work closely with the UK. He was so strongly against communist ideas that his hatred caused difficulties in building relationships with the Soviet Union and China. However, in 1959, he anticipated that the defense pact with the UK could not be permanent. Therefore, more attention was given to Malaysia's neighbors in Southeast Asia for economic treaties. Malaya, along with Thailand and the Philippines, established the Association of Southeast Asia (ASA), which had its first foreign ministers' meeting in 1961. After that, Malaysia, the Philippines, and Indonesia founded the Greater Malayan Confederation or Maphilindo, although it proved to be rather short-lived (Milne \& Mauzy, 1999). This period can be understood as a stabilizing era of Malaysian history, in which the Prime minister tried to stabilize the country's position in the region.

The second Prime Minister's (Tun Razak) administration's greatest crisis in foreign policy was the involvement of the United States in the Vietnam conflict (Means, 1991). His initiation was the announcement in September 1970 in which Malaysia proposed the neutralization of Southeast Asia to avoid great power conflicts in the region. The policy was accepted and guaranteed by the major powers. Razak's moves in foreign policy in the 1970s toward neutrality had been followed for a long time. This policy was replaced by the alternative policy of "Zone of Peace, Freedom and Neutrality, free from any form or manner of interference from outside powers", known as ZOPFAN (Means, 1991). The neutrality, however, could not be effective without considering China's appropriate international role. Therefore, Malaysia began to establish a peaceful basis of relationship between the two countries in 1974 (Milne \& Mauzy, 1999). In the same fashion, Malaysia attempted to have peaceful relationships with third world countries, including both Islamic and non-Islamic ones.

Hussein Onn became the Prime Minister in 1976, a period of service which lasted for only five years due to having been plagued by poor health for much of his term. He attempted to stabilize the security situation in the Indo-China area by contacting major powers, in particularly the Soviet Union (Means, 1991). Two important multilateral agreements were endorsed thereafter (Milne \& Mauzy, 1999). The first one was the ASEAN Treaty of Amity (1976), whose main purpose was to prevent disputes regarding regional peace and harmony from arising through friendly negotiations or good offices, mediation, inquiry or conciliation ("Treaty of Amity and Cooperation"). The second one was Cooperation and the Declaration of ASEAN Concord, of which the main purpose was to serve the stability of each of the member states ("Declaration of ASEAN Concord").

After Hussein Onn, Dr Mahathir Mohamad was elected prime minister in 1981. He brought a significant change to Malaysia's foreign policy. ASEAN was ranked first, followed by the Islamic countries and the Non-Aligned Movement (NAM) in second and third place, respectively. He held Japan in higher esteem than he did Britain. The "Look East" policy of Mahathir, which was mainly oriented towards Japan and South Korea, showed his inclinations in foreign policy. In other words, he wanted to grant Malaysia a more active role in international 
affairs through a foreign policy of active internationalism. He was successful in "putting Malaysia on the world map". Therefore, by the latter half of the 1980s, several international organisations acknowledged Malaysia's growing recognition (Harun, 2009). His other policies included "citing apartheid in South Africa, the subjugation of Namibia, and the damage to the economies of poor countries by the policies of rich and powerful countries" (Milne \& Mauzy, 1999).

When Dr Mahathir resigned in October 2003, his deputy Abdullah Ahmad Badawi became Prime Minister. Under Abdullah, Malaysia opted for a soft style of diplomacy. He believed that "a good foreign policy will make other countries comfortable in dealing with Malaysia" (Harun, 2009). The initiative of his foreign policy was pragmatism in foreign policy and having an influential leadership role as Chair of the Non-Aligned Movement (NAM), the Organisation of Islamic Conference (OIC) and ASEAN. It is important to mention that Badawi's emphasis on progressive Islamic ideas, or Islam Hadhari, in which tolerance was the corner stone of the idea, was helpful in foreign policy ("Malaysian Foreign Policy"). However, there was continuity during Abdullah's term. His top foreign policy priority was the East Asia Summit process. Abdullah improved relations with Australia, which had been frosty during Mahathir's administration (Harun, 2009).

After Abdullah, Najib Tun Razak, the son of the second Prime Minister of Malaysia, became Prime Minister. Since his coming to power, Seri Najib has visited many countries, including Indonesia, Brunei, Singapore, China and France. If at all 'country visits' can be considered the priorities of foreign policy, then Najib's inclination would be towards the East Asian region, especially ASEAN and China (Harun, 2009). These priorities demonstrate also the continuity in his foreign policy. During his Prime Ministry, Malaysia has attempted to improve its relations with countries in Asia Pacific, the Middle East, Africa and Latin America. Malaysia is trying to enhance its engagement in the international sphere through greater trade liberalization in the Asia-Pacific region and the Trans-Pacific Partnership and multilateral FTA initiative, which involves nine countries, namely Australia, Brunei, Chile, Malaysia, New Zealand, Peru, Singapore, the US and Vietnam. Besides these efforts, Malaysia has attempted to advance its political and economic cooperation with the European Union. On a multilateral level, the Prime Minister's initiative of "Global Movement of Moderates" in the 65th Session of the United Nations General Assembly (September 2010) ("Malaysian Foreign Policy") showed the Malaysian orientation toward tolerance and anti extremist ideas in foreign policy.

\section{Conclusion}

The domestic and foreign policies of Malaysia show that there has been continuity and the same principles of interaction in terms of economic and political/security approaches in both domestic and foreign spheres. In other words, Malaysia has been replicating her security approaches in domestic affairs towards ethnic and religious groups in foreign policy. Therefore, the general policy of Malaysia has been one of toleration and peaceful coexistence, rather than challenging and competition in both domestic and foreign affairs. In terms of domestic policy, although the government has been dominated by Islamic principles, and some privileges have been granted to Bumiputras, other religions and ethnicities have been free to follow their own traditional and religious ceremonies and economic endeavours. The ethnic riots of 1969 challenged the security of Malaysia, but at the same time made the government more aware of the consequences of ethnic struggles; as a result, they have made an effort to avoid future ethnic and religious strife. In other words, the Malaysian government has attempted to create conditions in which all ethnic groups coexist peacefully on the basis of toleration.

In the same fashion, the policy of toleration and peaceful coexistence in domestic affairs has been replicated in the realm of foreign policy as well. There can be seen continuity in the grand policies of all of the prime ministers of Malaysia since independence, was all of which have been based on toleration and peaceful coexistence, as well as cooperation with countries in and out of the region. The main goal of the first Prime Minister, Abdul Rahman, was to establish Malaysia's position in the region through economic and political treaties in Southeast Asia. The second Prime Minister, Tun Razak, followed the neutralization policy, which was completed through ZOPFAN in order to prevent the great powers' intervention in the region. He tried to enhance Malaysia's relations with China and the Soviet Union in order to achieve the stated goals. The third Prime Minister, Hussein Onn, sought to stabilize the security situation in the Indo-China region and emphasized two multilateral agreements, namely the ASEAN Treaty of Amity and the ASEAN Concord. There was continuity in the policies of the fourth Prime Minister Mahathir Mohamad, as well as in those of the fifth Prime Minister, Ahmad Badawi, both of whom were successful in following active internationalism in order to introduce Malaysia to the world, mostly through international organizations. The sixth Prime minister, Najib Razak, has tried his best to demonstrate Malaysia's moderate and anti-extremist policy in foreign affairs.

Generally, Multilateralism is the grand policy that Malaysia has followed since its independence. Multilateralism 
has compelled Malaysia to participate in many international organizations, especially in Asian regional organizations. In following a neutrality policy, Malaysia has endorsed the principle of non-alignment since 1970. During Mahathir's period, the non-alignment policy became clearer. Though Malaysia has been criticizing structure of the UN Security Council, she has been always supportive of the UN in general, as Mahathir in his address to the 50th session of the UN General Assembly evinced by stating that the UN is the only truly multi-national organization where the "voices of small nations can be heard" (Milne \& Mauzy, 1999). Malaysia was a founding member of ASEAN in 1967, which was the cornerstone of Malaysian foreign policy goals and strategies. The basis of ASEAN was to avoid confrontation and promote the peaceful resolution of conflicts in the region. Enhancing regional trade and economic development was another objective of ASEAN. As a member of APEC, Malaysia emphasized trade liberalization and diversification policy. "Open regionalism" is the central concept of APEC activities, which were to grant trade liberalization to all its members (Milne \& Mauzy, 1999).

\section{References}

Ahmad, A. M., \& Rahman, S. N. A. (2001). Civilizational Islam: Promulagating the New Approach of Islam in Malaysia. A Journal of the Pacific and Asian Communication Association, 12(1.2.3.4).

Amiri, R. E., Khorshidi, M., \& Soltani, F. (2011). Duplicate of domestic behavior in Iran's foreign policy arena during Khatami presidency. Elixir Journal, 38, 4073-4078.

Aun, L. H. (2004). Development in Malaysia: Economics and Politics of an Idea. Academika, (64).

Caprioli, M., \& Boyer, M. A. (2001). Gender, Violence, and International Crisis. Journal of Conflict Resolution, 45(4), 503-518. http://dx.doi.org/10.1177/0022002701045004005

Caprioli, M., \& Trumbore, P. F. (2003). Identifying 'Rogue' States and Testing their Interstate Conflict Behavior. European Journal of International Relations, 9(3), 377-406. http://dx.doi.org/10.1177/13540661030093002

Doyle, M. W. (1986, December). Liberalism and World Politics. The American Political Science Review, 80(4), 1151-1169. http://dx.doi.org/10.2307/1960861

Fox, J., \& Sandler, S. (2003). Regime Types and Discrimination against Ethnoreligious Minorities: A Cross-Sectional Analysis of the Autocracy-Democracy Continuum. Political Studies, 51, 469-489. http://dx.doi.org/10.1111/1467-9248.00436

Gurr, T. R. (1993). Why Minorities Rebel: A Global Analysis of Communal Mobilization and Conflict Since 1945. InternationaPl olitical ScienceR eview, 14(2).

Harun, R. (2009). In Pursuit of National Interest: Change and Continuity in Malaysia's Foreign Policy Towards the Middle East. International Journal of West Asian Studies, 1.

International Law. (2010). Declaration of ASEAN Concord. Retrieved November 11, 2012, from http://www.dipublico.com.ar/english/declaration-of-asean-concord/

Jawan, J. A. (2003). Malaysian Politics and Government. Shahalam: Karisma Publications.

Kessler, C. (2012). May 13, 1969: A regime crisis. Retrieved November 19, 2012, from http://www.themalaysianinsider.com/sideviews/article/may-13-1969-a-regime-crisis-clive-kessler

Kuok, L. (2008). Security First: The Lodestar for U.S. Foreign Policy in Southeast Asia? American Behavioral Scientist, 51(9). http://dx.doi.org/10.1177/0002764208317233

Lichbach, M. I., \& Gurr, T. R. (2010). The Conflict Process: A Formal Model. The Journal of Conflict Resolution, 25(1), 3-29. http://dx.doi.org/10.1177/002200278102500101

Lijphart, A. (1977). Democracy in Plural Societies: A comparative exploration. New Haven, Yale University Press.

Index Mundi. (2011). Malaysia Demographics Profile 2012. Retrieved November 20, 2012, from http://www.indexmundi.com/malaysia/demographics_profile.html

KLN. (n. d.). Malaysian Foreign Policy. Retrieved November 20, 2012, from http://www.kln.gov.my/web/guest/evolution

Means, G. P. (1991). Malaysian Politics: The Second Generation. Oxford, Oxford University Press.

Regan, P. M., \& Paskeviciute, A. (2003). Women's Access to Politics and Peaceful States. Journal of Peace Research, 40(3), 287-302. http://dx.doi.org/10.1177/0022343303040003003 
Milne, R. S., \& K. Mauzy, D. (1999). Malaysian Politics under Mahathir. New York, NY: Routledge.

Ministry of Foreign Affaires of Japan. (1976). Treaty of Amity and Cooperation in Southeast Asia. Retrieved November 10, 2012, from http://www.mofa.go.jp/region/asia-paci/asean/treaty.html

U. N. D. P. (United Nations Development Programme: Project Document). (2004). Strengthening Capacity in Poverty Monitoring, Policy Formulation and Evaluation. Retrieved November 10, 2012, from http://www.undp.org.my/uploads/Project_doc_Poverty_Monitoring_Policy_Formulation.pdf 